\title{
POR QUE NÃO PODEMOS VER A DIVERSIDADE RELIGIOSA: QUESTIONANDO O PARADIGMA CATÓLICO-CÊNTRICO NO ESTUDO DA RELIGIÁO NA AMÉRICA LATINA ${ }^{1}$
}

\section{Alejandro Frigerio ${ }^{2}$}

Resumo: Os avanços nos estudos da religião na América Latina se tornam restringidos pela persistência de visóes excessivamente católicas-cêntricas que impedem a compreensão adequada à extensão e à relevância da diversidade religiosa, a relegando a um mero epifenômeno recente e minoritário da nossa realidade social. A natureza real do papel do catolicismo no continente poderia ser melhor avaliado e compreendido - nas suas diferentes dimensóes - se deixarmos de aceitar sem críticas uma série de suposições e princípios básicos que orientam nossa análise e que tentarei repensar neste trabalho. Para fazer isso, procuro identificar as características mínimas do que considero um paradigma analítico dominante no estudo da religiáo nas ciências sociais (principalmente a sociologia) e fornecer uma visão alternativa, baseada em diferentes pressupostos teóricos. Argumento que a dependência nos postulados de alguns autores canônicos, a excessiva comparação entre "identidades" e "crenças" e a adesão a visões extremamente institucionalizadas sobre a religião, bem como a pouca atenção dada às diferentes formas de regulamentaçôes religiosas, fornecem uma visão exagerada de uma "América Latina católica".

Palavras-chave: Religiāo; Catolicismo; Diversidade Religiosa; Teoria; Espiritualidade.

Abstract: Advances in the study of religion in Latin America have been hindered by the persistence of excessively Catholic-centric visions that cannot adequately account for the extension and relevance of religious diversity in the area, considering it a

1 Tradução: Adriana Kerchner da Silva, aluna do curso de Bacharelado em Letras Tradução Português/Espanhol, UFRGS. Supervisão: Cleci Regina Bevilacqua, professora do Departamento de Línguas Modernas, Instituto de Letras, UFRGS. Revisão técnica: Luciana Alvarez (Unicamp).

2 Graduado em Sociologia pela Universidade Católica Argentina (UCA). Doutor em Antropologia pela Universidade da Califórnia. Pesquisador independente do Conselho Nacional de Pesquisas Científicas e Técnicas (CONICET). Contato: alejandrofrig@yahoo.com.ar 
mere recent and minor epiphenomenon of its social reality. The real scope of this relevance, as well as a more nuanced view of the centrality of Catholicism, could be understood if we started questioning several presuppositions that usually guide our analysis and that I will reconsider in this article. In order to do this, I will first identify the basic traits of what I consider to be the dominant paradigm in the study (especially in the sociology) of religion and then I will provide an alternative view, based on different theoretical principles. I will argue that the overdependence on premises provided by certain canonical authors, the unwarranted equalization of "identities"; with "beliefs"; and the acceptance of excessively institutionalized views of "religion", as well as the scant attention paid to religious regulation, result in an exaggerated idea of how "Catholic" Latin America really is.

Keywords: Religion; Catholicism; Religious Diversity; Theory; Spirituality.

Os avanços no estudo da religião na América Latina foram restringidos pela persistência de visóes excessivamente católico-cêntricas que impedem que se entenda adequadamente a extensão e a relevância da diversidade religiosa relegando-a a um mero epifenômeno recente e minoritário de nossa realidade social. A real natureza do protagonismo do catolicismo no continente poderia ser melhor avaliada e compreendida - em suas distintas dimensóes - se deixássemos de aceitar acriticamente uma série de pressupostos básicos que guiam nossas análises e que tentarei reconsiderar neste trabalho. ${ }^{3}$

3 Este trabalho baseia-se na conferência que proferi no Instituto de Investigaciones Sociales da Universidad Nacional Autónoma de México (UNAM), México, em abril de 2015, no Seminario Permanente de Cultura y Representaciones Sociales. Agradeço a Hugo José Suárez e a Gilberto Giménez pelo convite. Reelaboraçôes posteriores foram apresentadas também como conferências no Programa de Pós-Graduação em Antropologia Social da Universidade Federal do Rio Grande do Sul (UFRGS), em Porto Alegre (2015) e no Programa de Pós-graduação em Ciências das Religiōes da Universidade Federal da Paraíba (UFPB) em João Pessoa (2016). Agradeço a todos(as) colegas pelas sugestóes recebidas nessas apresentaçóes. Escutei pela primeira vez o termo "católico-centrismo" em uma exposição de Pablo Semán na X Reunión de Antropología Social realizada em Córdoba (2013) (ver também Semán, 2013). 
Para tanto, identificarei os traços mínimos do que considero um paradigma analítico dominante no estudo da religião na perspectiva das ciências sociais (principalmente a sociologia) e apresentarei uma visão alternativa, baseada em pressupostos teóricos diferentes.

Argumentarei que a exagerada dependência nos postulados de alguns autores canônicos, a excessiva equiparação de "identidades" com "crenças" e a adesão a visóes demasiadamente institucionalizadas da religiáo, assim como a escassa atençáo às distintas modalidades da regulação religiosa, oferecem uma visão exagerada de uma "América Latina católica" - quando sempre foi evidente que a crença nos seres sobrenaturais propostos pela Igreja era, ao mesmo tempo, acompanhada, quando náo contestada, por uma náo menos relevante diversidade de crenças em muitos outros seres espirituais náo reconhecidos por ela ou por maneiras muito diferentes de se relacionar com os que ela postulava. A visão quase universalmente aceita de um monopólio católico como condição "natural" das sociedades da região, quebrado táo somente nas últimas décadas - principalmente pelo avanço pentecostal -, propicia uma visão estereotipada e simplificada da religiâo nas nossas sociedades que, ao criar uma situaçáo exagerada de um "antes" (monopólico) e um "depois" (plural), impede que se veja a contínua existência de diversidade religiosa. Uma diversidade cuja relevância social também foi pouco apreciada por sua tênue visibilidade social, já que sempre foi fortemente regulada - mas não suprimida - pelas diversas instituiçôes do Estado e combatida por atores sociais de prestígio - não apenas religiosos, mas também seculares, como os médicos, psicólogos e jornalistas. Esses prolongados e denodados esforços sociais para controlar práticas e vozes religiosas dissidentes (não católicas) têm sido pouco considerados ou estudados, já que os acadêmicos naturalizamos a hegemonia do catolicismo, ajudando a invisibilizar a diversidade, deslocando-a a categorias residuais como "religiosidade popular", "curandeirismo" ou "esoterismo".

De modo mais geral, proponho também que uma visão menos cognitiva e sistematizada de (o que seria a) "religião" permitiria focar na rica criação e circulaçáo de conteúdos religiosos por fora das instituiçôes tradicionalmente 
consideradas "religiosas", em grupos e contextos muito diversos e em articulação com aspectos modernos e seculares da vida social como a indústria cultural, os meios de comunicação e internet e as redes sociais. Reunirei e resumirei, neste trabalho, ideias previamente desenvolvidas mais extensamente em outros artigos de minha autoria e aqui enfatizarei mais o argumento relativo a nossas visões excessivamente institucionalizadas da religião. ${ }^{4}$

Utilizando autores e perspectivas teóricas diferentes das habitualmente utilizadas na região, tentarei apresentar leituras alternativas do monopólio religioso, das identidades religiosas, do pluralismo e da regulação religiosa e, principalmente, das características necessárias da "religião". As análises derivadas dessas releituras conceituais tornariam mais significativa e relevante a presença (passada e atual) da diversidade religiosa, mais visíveis as distintas maneiras de regulação religiosa e mais evidentes os preconceitos acadêmicos que a ocultam.

\section{O PARADIGMA DOMINANTE NA ANÁLISE SOCIOLÓGICA DO CAMPO RELIGIOSO NA AMÉRICA LATINA}

Com a expressão paradigma dominante, designarei uma série de pressupostos básicos que costumam guiar a maior parte das análises, baseados na hegemonia de certas perspectivas teóricas e definiçóes conceituais de determinados autores, amplamente aceitos de maneira implícita, que sedimentam um sentido comum acadêmico, no que "todos nós sabemos" sobre a situação da religiáo na modernidade latino-americana - com algumas diferenças conforme os diferentes países.

4 Para que a minha proposta fique mais clara, reproduzo parte dos argumentos que já desenvolvi sobre: os distintos tipos de identidades e a superdimensão do monopólio religioso católico (Frigerio, 2007); o pluralismo e a regulação religiosa (Frigerio; Wynarczyk, 2008); a diversidade religiosa (Frigerio 2013a e Frigerio; Wynarczyk, 2013) e a espiritualidade contemporânea (Frigerio 2016 e 2013b). 
A formulação mais resumida - e estereotipada, admito - do que poderiam ser os pressupostos básicos do paradigma dominante seria a seguinte: Existiu um monopólio católico que foi quebrado nas últimas três ou quatro décadas - conforme o pais. Essa ruptura do "monopólio católico" levaria a uma situação de pluralismo religioso e a um mercado de bens simbólicos de salvação, no qual cada individuo já não seria "refém" da oferta eclesial e buscaria novas crenças e identidades entre as crescentes ofertas religiosas - ou construiria sua própria sintese, em um processo crescente de individualização das crenças. ${ }^{5}$

Longe de ser uma visão meramente local (argentina), essa perspectiva é compartilhada por boa parte dos estudiosos latino-americanos, já que se deriva de uma visão maior sobre as relaçôes entre religião e modernidade proposta por autores de grande prestígio na regiáo - especialmente Peter Berger e Daniele Hervieu-Léger, referências praticamente obrigatórias ao se proporcionar um panorama do campo religioso atual. ${ }^{6}$ Para comprová-lo, basta comparar os marcos teóricos de três importantes estudos quantitativos sobre as crenças contemporâneas realizados na cidade de Montevidéu, Uruguai (da Costa, 2003, p. 5-37), na de Guadalajara, México (Fortuny, 1999, p. 17-29) e no distrito de Quilmes, na Grande Buenos Aires, na Argentina (Esquivel et al., 2001, p. 33-38; Mallimaci, 2001, p. 17-24).

Nesses estudos, após as críticas à visão sociológica clássica sobre a secularização que acompanharia a vida moderna, com a consequente perda de

5 Para outra perspectiva, ver Bastian: "A América Latina vive uma transformação religiosa caracterizada pela diversificação dos pertencimentos confessionais e por uma pluralização da crença [...]. O campo religioso latino-americano passou [...] de uma efervescência diferenciada em situação de monopólio a uma pluralização efervescente” (2006, p. 66-68).

6 Principalmente, a concepção de Peter Berger (1971) da religião como um "dossel sagrado" e das consequências que a passagem de uma situação de monopólio para uma de pluralismo religioso tem na fragilização das crenças, e as ideias de Hervieu-Léger sobre o tipo de reconstituição que sofreria a religião na modernidade: a crença "se expressa de forma individualizada, subjetiva, dispersa e por meio da multiplicidade de significaçóes que os indivíduos elaboram de maneira cada vez mais independente do controle das instituiçóes da crença (e, em particular, das instituiçóes religiosas)” (Hervieu-Léger, 1993, p. 109).

Debates do NER, Porto Alegre, ano i9, N. 34, P. 75-I 2 I, Ago./DeZ. 20 i 8 
importância ou desaparecimento da religião, são reiteradas as citaçóes aos trabalhos de Hervieu-Léger, segundo os quais a secularização seria "não a perda da religiáo em uma sociedade globalmente racionalizada, mas uma reorganização geral das formas de religiosidade" (1998, p. 20). A diversificação religiosa, a individuação da crença e a ruptura da memória coletiva seriam os traços principais dessa reorganização da religião. Essa perspectiva ressalta a continuada importância da religião, mas (ao menos na maneira em que se popularizou regionalmente) acentua uma situação de "antes" $e$ de "depois" que, proporcionando uma visão um tanto estereotipada do passado monopolizado pelo catolicismo, singulariza em demasia o caráter inovador da dinâmica religiosa atual. Perante a ausência, ao menos para vários países latino-americanos, de dados quantitativos sobre a situação das crenças religiosas no passado, a maior parte das pesquisas quantitativas cotejam a situaçáo atual com o suposto passado oferecido por essa perspectiva teórica. Portanto, os dados empíricos atuais são lidos comparando-os, explícita ou implicitamente, com um passado determinado não pela empiria, mas pela teoria, e a novidade da situação atual decorre da comparação com um passado hipotético, no qual o catolicismo pareceria exercer o papel de dossel sagrado de nossas sociedades.

Renée de la Torre (1999, p. 130), em um dos trabalhos que examinam os dados da pesquisa sobre crenças e religiosidade em Guadalajara, México, reconhece francamente esse problema:

Como precisar a mudança religiosa sem ter claro o antes e o depois? O que hoje em dia se reconhece como impacto da secularizaçáo poderia ser uma derivação de processos de longa duração, como, por exemplo, a religiosidade popular? [...] não contamos com estudos similares que nos permitam comparar o antes e o depois no contexto espacial de Guadalajara, pelo que tâo somente podemos recriar um antes através de um imaginário do estado das coisas pouco preciso. 
Essa limitaçáo, inerente a quase todos os trabalhos de pesquisa atuais sobre religião, não é suficientemente reconhecida. ${ }^{7} \mathrm{E}$ o "imaginário pouco preciso" que utilizamos para recriar o passado, ainda menos. Na versão mais usual, nesse passado o monopólio religioso católico teria determinado tanto as identidades religiosas como as crenças dos indivíduos e compreenderia todas as suas práticas religiosas. Essa visão dominante funde dimensóes cuja correlação não deveria ser considerada assentada, mas que deveria ser objeto de exame. Em um trabalho anterior (Frigerio, 2007), propus que o catolicismo, na verdade, apenas teria a incidência que lhe é atribuída principalmente sobre as crenças e práticas religiosas socialmente legítimas. A forte legitimidade social imporia uma identificação social correspondente (a de “católico”), mas esse predomínio seria muito menos efetivo sobre as crenças e práticas religiosas reais (e não já socialmente legítimas ou estabelecidas).

Resumindo, então, a perspectiva dominante sobre o monopólio católico: o catolicismo era a religião monopólica que dava sentido, crenças e identidade à população. Por uma série de mudanças sociais (ocorridas tanto na Argentina como em outras sociedades latino-americanas e em nível global com o advento da modernidade), rompe-se esse monopólio e cria-se um mercado religioso. Nele, cada indivíduo escolhe a que grupo quer pertencer (ou realiza sua própria síntese de crenças, em uma espécie de "religiáo à la carte" e "contapropismo religioso" ${ }^{8}$. ${ }^{\text {? }}$

Inseridos nessa formulação, ao mesmo tempo resumida e muito genérica, há outros pressupostos que constituem parte da nossa bagagem analítica usual

7 A pesquisa de da Costa (2003) é uma bem-vinda exceção a essa regra. Tomando quatro trabalhos distintos (ainda que comparáveis), consegue uma sequência de dados de cinquenta anos que mostra uma série de interessantes oscilaçóes nas crenças.

8 N. T.: o texto original usa o termo espanhol "cuentapropismo". Ideia de "por conta própria".

9 Sem dúvida estou simplificando excessivamente o que chamo de perspectiva dominante do monopólio católico. Confio, entretanto, que será evidente para xs leitorxs sua familiaridade com essas ideias, assim como sua popularidade acadêmica. De todo modo, meu objetivo não é tanto realizar uma crítica pormenorizada desse paradigma, mas oferecer visóes alternativas de análise. 
e que criticarei mais detalhadamente a seguir: a (exagerada) importância dada às identidades religiosas como forma de medir o monopólio e a subsequente quebra deste (a transição de um estado a outro é usualmente medida e especificada pela quantidade decrescente de pessoas que se identificam como “católicas"); a (con)fusão entre identidades e crenças; a pouca atenção dada às diferentes maneiras de regulação religiosa que ainda persistem - enfatizando fortemente, dessa forma, o "pluralismo" ou a situação de (livre) mercado religioso atual. Também serei crítico da ideia, mais implícita do que efetivamente enunciada (tendemos a usar o conceito sem definiçóes explícitas), de que a "religiáo" é principalmente um sistema de símbolos - que aludem a realidades últimas de significado ou a planos sagrados da existência - e que ela se transmite principalmente através de grupos religiosos, que, para sê-lo (e por sê-lo), possuem determinadas características - tampouco explicitadas e pouco contestadas; os modelos mais cristãos de igreja ou seita sendo os modelos habituais.

\section{UMA VISÃO ALTERNATIVA SOBRE O MONOPÓLIO, O PLURALISMO, A REGULAÇÃO E AS IDENTIDADES RELIGIOSAS}

A seguir apresentarei visóes alternativas sobre o "monopólio" e o pluralismo religiosos, as identidades (identificaçôes) religiosas e a maneira como podemos visualizar e definir a "religiāo". Não pretendo que essas sejam as maneiras "objetivas", nem "mais adequadas" de pensar esses temas e de definir esses conceitos, mas sim que evidenciem aspectos da realidade que, do contrário, passam despercebidos - especialmente os relacionados com a visibilização e a regulação da diversidade religiosa.

Sobre o MONOPÓlio RELIGIOSO CATÓLICO

É preciso compreender e reconhecer que o "monopólio católico" sempre foi principalmente sobre as "crenças (socialmente) legítimas" e não sobre as 
crenças (efetivas) das pessoas. ${ }^{10}$ As pessoas sempre tiveram crenças muito diferentes das indicadas pela Igreja Católica, algo que fica claro pela contínua e popular presença de crenças e de práticas "mágicas”, "esotéricas” e de espiritualidades alternativas - sempre combatidas pelo Estado e pelos médicos, ademais dos sacerdotes católicos. ${ }^{11}$

$\mathrm{Na}$ Argentina, pelo menos desde o princípio do século XX, essas presenças são advertidas nos principais jornais e combatidas por campanhas jornalísticas que aplaudem - e incentivam - a ação policial contra "curandeiras" e "adivinhas" que frequentemente terminam detidas nas delegacias. Apesar da sequência de antecedentes históricos inegáveis, a cada década ou duas, os meios voltam a retomar esse "problema", apontando-o com estranheza, como uma anomalia que não deveria estar ali. Bruxas, curandeiras, adivinhas, espiritistas e praticantes de espiritualidades mágico-religiosas diferentes do cristianismo são ignorados ou, se percebidos, estigmatizados, devido a nossa imagem ideal do país como "europeu", "branco", "moderno" e "católico", sem lugar para religióes alternativas e muito menos para a "magia" ou para visóes encantadas do mundo (Frigerio, 2002). ${ }^{12}$

${ }^{10}$ Aqui me refiro principalmente ao caso argentino. A afirmação deveria ser válida também para muitos outros países latino-americanos, embora fosse necessário qualificar sua relevância em cada caso.

11 Sobre a antiguidade e persistência da diversidade religiosa na Argentina, ver Bianchi (2004) e consultar o dossiê "Del "monopolio católico" al "pluralismo": ¿qué lugar para la diversidad religiosa en Argentina?” na revista Corpus (2013), com textos de antropólogos, historiadores e sociólogos. Disponível em: <https://corpusarchivos.revues.org/162>. Acesso em: 14 set. 2018.

12 O historiador Roberto Di Stefano destaca: "Se hoje consideramos que, embora a esmagadora maioria dos argentinos se declara católica nas pesquisas, o dado é enganoso porque esconde religiosidades ou espiritualidades autoconstruídas, não me parece que no século XVIII as coisas fossem muito diferentes. Já afirmei: nem os padres das paróquias urbanas de Buenos Aires conseguiram que seus fiéis cumprissem com o preceito anual no século XVIII. Se lemos os relatórios dos padres de outras áreas, sobretudo das rurais, nos deparamos com situaçóes parecidas [...]. Quase ao final do século XIX, consideravam-se os argentinos como católicos e os protestantes como estrangeiros. Mas

Debates do NER, Porto Alegre, ANo I9, N. 34, P. 75-I 2 I , Ago./DeZ. 20 I 8 
A abundante evidência empírica local sobre esses agentes mágico-religiosos também foi maiormente invisibilizada pela academia local e, quando tratada, foi deslocada para o campo do "esoterismo" ou do "curandeirismo", mais do que o propriamente "religioso" - mediante definições no mínimo questionáveis dessas categorias e efetuando um recorte muito parcial da ampla gama de atividades que muitos desses curandeiros ou adivinhos realizam, já que usualmente oferecem tanto bens mágicos quanto religiosos para seus clientes/devotos. ${ }^{13}$

Igualmente, a enorme quantidade de "santos populares" e seres espirituais de todo tipo aos quais se rende culto - por mais heterodoxos e distantes do santoral católico que sejam - são normalizados, invisibilizados, menosprezados ou contidos pelos acadêmicos, que os colocam dentro do "catolicismo popular", desenfatizando conceitualmente sua alteridade religiosa radical. A presença cada vez maior de todo tipo de religióes de origem afro e a prolongada vigência do espiritismo (desigual nos diferentes países) também é subestimada, já que não produzem identificaçôes sociais fortes (ver mais abaixo) ou as ocultam. ${ }^{14}$

De maneira mais geral, para realizar uma crítica às visôes que exageram a fortaleza do monopólio católico no passado argentino, também parto de embasamentos teóricos diferentes: não da ideia de Peter Berger de um "dossel

essa homologação não reflete nenhuma unanimidade de crenças, mas responde ao fato de que a adscrição religiosa tinha implicaçôes políticas e jurídicas.” (2013, p. 2).

${ }^{13}$ Com exceção do pioneiro trabalho de Bianchi (2004) que fala de "minorias religiosas", outros importantes estudos de historiadores que abrangem crenças e práticas que expressam diversidade religiosa preferem situá-los dentro do "esoterismo" (Bubello, 2010), do "ocultismo" (Santamaría, 1992; Quereilhac, 2016) ou do "curandeirismo" (Chavez; Maurizi; Horvath, 1977; Ratier, 1972). Wright e Messineo (2013, p. 31) utilizam a expressão "heterodoxias sócio-religiosas" porque "ocupam um lugar periférico no campo (religioso)".

${ }^{14}$ Por esse motivo, dificilmente figuram nos números de crentes religiosos oferecidos por estudos quantitativos, por mais que a presença de "pais" e "máes" de umbanda seja muito comum nos bairros da Grande Buenos Aires. 
sagrado" - compartilhada por boa parte dos acadêmicos da área -, mas das ideias de James Beckford e de Rodney Stark e associados, que consideram a pluralidade de visóes religiosas não uma exceção recente, mas uma situação natural em sociedades complexas - que a instauração de monopólios religiosos suprimiu ou controlou com grande esforço e, geralmente, com cumplicidade estatal.

Beckford aponta que a concepção tradicional do termo "monopólio" foi influenciada, em grande medida, pelos "escritos quase canônicos" de Peter Berger e Thomas Luckmann. Concentrando-se principalmente nos trabalhos do primeiro autor, sustenta que "o ponto de partida de Berger, a afirmação segundo a qual 'através da maior parte da história humana os establishments religiosos existiram como monopólios na sociedade (1971, p. 134)' é, se muito, uma afirmação discutível e, provavelmente, equivocada” (2003, p. 82).

Segundo o sociólogo britânico:

Parece difícil afirmar que o monopólio religioso alguma vez significou a total ausência de diversidade religiosa [...]. Assim, o contraste de Berger entre "tradição" e "modernidade" é exagerado [...]. [Esta visão] ignora o fato de que os sentimentos e as crenças religiosas quase sempre foram diversos e menospreza a força e o esforço que devem ter sido feitos para manter a ficçáo de um mundo unitário de verdade religiosa (Beckford, 2003, p. 83).

Em sua perspectiva, os conflitos entre visóes de mundo existentes no começo da modernidade:

[...] refletem mais uma diminuição na capacidade dos que tinham poder para suprimir dissidência do que uma perda de fé em uma única fonte de verdade. As perguntas sociológicas interessantes não versam sobre a credibilidade de algum tipo de afirmação religiosa de verdade, mas sobre as condiçôes sociais que permitiram que uma variedade de crenças, práticas e organizaçóes adquirissem aceitação, permissão ou legitimidade. $\mathrm{O}$ enfoque deveria estar sobre o poder e a violência mais do que na suposta perda ou diminuição do monopólio sobre a verdade e o surgimento do relativismo filosófico (Beckford, 2003, p. 83-84, destaque nosso). 
Rodney Stark, Roger Finke e Lawrence Iannaconne argumentaram em diversos trabalhos, em coautoria ou não - que o pluralismo - e não o monopólio - é a situação natural de economias religiosas - ao menos em sociedades complexas -, já que a segmentação inevitável das preferências dos atores sociais (por classe social, sexo, idade, etc.) impossibilita que uma só oferta religiosa possa satisfazer todas as suas necessidades:

Como uma única firma religiosa não pode moldar seu atrativo para atender as necessidades de um segmento do mercado sem sacrificar seu atrativo para outro, a oferta e a diversidade da religiáo aumentam na medida em que as regulaçôes são revogadas [...]. Devido à diferenciação subjacente às preferências dos consumidores, a concorrência religiosa e o pluralismo crescerão, salvo que exista uma regulação do Estado (Finke, 1997, p. 51).

Uma única firma religiosa pode monopolizar a economia religiosa somente na medida em que pode empregar a força coercitiva do Estado para regular e restringir seus concorrentes (Stark; Iannaconne, 1993, p. 252).

Esses autores desconfiam, inclusive, de que alguma vez tenha existido um monopólio católico efetivo:

Porque essas preferências dos consumidores são fortes, as economias religiosas nunca podem ser plenamente monopolizadas, nem mesmo quando estão respaldadas pelo poder coercitivo total do Estado. Dessa maneira, mesmo quando se encontrava no topo de seu poder temporal, a Igreja medieval estava rodeada de heresias e afetada por divergências internas (Stark; McCann, 1993, p. 113).

Sem negar a relevância que o catolicismo obviamente teve e tem em nossas sociedades, um embasamento teórico mais atento à dimensão do poder, e que náo naturalize a necessidade de um monopólio religioso, tornaria mais evidente a inevitabilidade da presença da diversidade religiosa (para satisfazer a distintos segmentos e grupos da população, com demandas e gostos religiosos muito diferentes) e, sobretudo, a forte regulação social que ocultou 
essa diversidade na época do suposto "monopólio". Ademais, valorizaria mais adequadamente a relevância das possibilidades de visibilidade que oferece a crescente desregularização religiosa. Para o caso argentino, é muito claro que a volta à democracia a partir de 1982 rompeu, aos poucos e não sem muito e progressivo esforço, com a identificação "nação = catolicismo = forças armadas" e permitiu que pentecostais, afro-umbandistas, espiritistas e a multiplicidade de propostas englobáveis sob o sempre impreciso rótulo de "Nova Era" ganhassem visibilidade. Muitas dessas crenças e práticas já estavam presentes no país, mas, dada a repressão estatal que várias delas sofriam (sob a acusação de "exercício ilegal da medicina” ou por outros motivos), mantinham um perfil cauteloso. Com a chegada da democracia, sua presença no espaço público tornou-se muito mais evidente, mas essa crescente visibilidade da diversidade religiosa logo deu espaço para uma forte reação social: a construção da "invasão das seitas" que, junto com a cumplicidade midiática e o ativo trabalho de um movimento contra-cultos local, gerou pânico moral no começo da década de 1990 (Frigerio, 1993; Frigerio; Oro, 1998; Frigerio; Wynarczyk, 2003).

Resumindo o argumento: a diversidade religiosa sempre foi mais importante no passado do que pensamos; foi invisibilizada tanto pelas prolongadas e intensas maneiras de regulação social implementadas contra ela, quanto pelos pressupostos acadêmicos que a deslocavam para as difusas categorias conceituais de "catolicismo popular", "esoterismo" ou "curandeirismo".

SOBRE A RELEVÂNCIA DAS IDENTIFICAÇŌES RELIGIOSAS (“IDENTIDADES”)

O paradigma dominante costuma menosprezar o caráter situado, contingente e relacional das identidades (as quais preferimos denominar identificaçôes para ressaltar seu caráter de produtos da interação social permanente e para não concebê-las como essências internas às pessoas) e apresenta uma versão inflada deste conceito - atribuindo-lhe uma importância muito superior à que tem. ${ }^{15}$

15 Seguindo o resumo que Weigert, D. Teitge e J. Teitge (1986) realizam das contribuições de diferentes autores situados dentro da corrente do interacionismo simbólico, podemos

Debates do NER, Porto Alegre, ANo I9, N. 34, P. 75-I 2 I , Ago./DeZ. 20 I 8 
Quando um censo oferece a informação de que $90 \%$ da população é católica, isso significa que essa porcentagem optou, perante uma pergunta pontual sobre afiliação religiosa, pela identidade social de católico. Esse ato pontual de identificação frente a uma pergunta concreta - e não muito frequente na vida de uma pessoa - não nos diz nada sobre que lugar ocupa o ser "católico" na sua estrutura de compromissos identitários e se essa identificação tem alguma relevância para sua identidade pessoal (seu self). ${ }^{16}$ Quando uma pessoa opta pela identidade social de católico, isso tampouco indica se ela se sente parte de um "nós" católico com intensidade suficiente para atuar coletivamente em benefício desse grupo ("católico" como identidade coletiva). ${ }^{17}$

conceber a identidade como "uma definição socialmente construída de um indivíduo" (1986, p. 34). Mais especificamente, como uma dimensão tipificada ou socialmente expressada do self (afirmação que deriva de Stone, 1962). Segundo Weigert, D. Teitge e J. Teitge, "um indivíduo possui um self que é tipificado situacionalmente através de uma variedade de identidades. As identidades constituem o self no contexto da ação social” (1986, p. 40). Ou seja, nosso self apenas é socialmente acessível mediante as identidades que se atribui ou que lhe são atribuídas.

${ }^{16}$ Uma característica dos indivíduos em sociedades complexas é que várias e mutantes definiçóes do self estâo disponíveis como identidades. Uma ou outra identidade pode ser apresentada pelo ator ou imposta por outros interagentes enquanto cada um negocia pelo controle da situação ou, ao menos, para estabelecer um consenso de trabalho. Os indivíduos devem enfrentar a tarefa de manejar continuamente identidades múltiplas dentro - e através - de situaçóes sociais (Weigert; Teitge, D.; Teitge, J., 1986, p. 46). O ordenamento das identidades em termos de grau e tipo de compromisso que cada ator tem com elas constitui a estrutura de compromissos identitários. Os indivíduos oferecem para sua validação uma identidade principal ou mestre (master identity) que representa uma organização implícita de todas as outras identidades (Weigert; Teitge, D.; Teitge, J., 1986, p. 51-53). É claro que a capacidade de negociar identificaçóes é mais limitada em determinados contextos que em outros - as identificaçóes raciais ou étnicas são menos negociáveis em sociedades racistas.

${ }^{17}$ Cada um desses termos denota um fenômeno social (e um objeto de estudo) diferente embora certamente inter-relacionados. A identidade pessoal seria "a conceitualização que a pessoa faz de sua continuidade como sujeito e de seus atributos [...] é o conceito que o indivíduo tem de si mesmo como um ser físico, social, espiritual e moral” (Carozzi, 
É necessário admitir, portanto, que a identidade social de católico não nos diz nada sobre a identidade pessoal do indivíduo, nem sobre sua identidade coletiva e muito menos nos diz sobre suas crenças. As identificaçôes dizem pouco sobre as crenças de quem as adotam: umas são respostas à pergunta "quem sou eu" (e/ou como me classificam os outros) e outras à pergunta "no que eu creio".

As mutantes e altamente variáveis relaçōes entre identificaçôes e crenças ficam evidentes se comparamos as que realizam os integrantes de diferentes grupos religiosos. Boa parte dos grupos e agentes produtores de diversidade religiosa (ou seja, que postulam determinados seres espirituais e maneiras de se relacionar com eles) não necessariamente propóem identificaçôes religiosas específicas. O caso mais claro é o dos cultores e praticantes da Nova Era, que dificilmente se identificam como tal - pela sua marcada ênfase na autonomia espiritual e na circulação por, mais que na permanência em, diferentes grupos. A identificaçáo de "praticante de disciplinas da Nova Era" tem escassa relevância no que se refere às identificaçôes pessoais, sociais ou coletivas. No entanto, a natureza supra-humana que postulam sobre determinados seres ou energias espirituais (seja de maneira transcendente ou imanente) e as maneiras que propóem de se relacionar com elxs ou de desenvolvê-las afetam a vida cotidiana de milhares e milhares de argentinos - independentemente de qual seja sua "identidade" religiosa. Para muitos, provavelmente seja a de "católicos", por mais que sua cosmovisão pouco corresponda com a postulada pela instituição religiosa à qual declaram pertencer.

1992 apud Goffman, 1986, p. 56-57). A identidade social seria "a categoria de pessoa adjudicada a um indivíduo mediante mecanismos de autoatribuição e atribuição por outros, no curso da interaçâo" (Carozzi, 1992). Essas categorias são sociais, reconhecidas pelos membros de uma sociedade e atribuídas durante as interaçóes sociais. A identidade coletiva é "a conexão cognitiva, moral e emocional de um indivíduo com uma comunidade maior [...]" (Polletta; Jasper, 2001, p. 85). Segundo Snow (2001), "imerso nesse sentimento coletivo de nós, há um sentimento correspondente de agência coletiva [...] na persecução de interesses comuns”. Ver Frigerio (2007) para um maior aprofundamento dessa diferenciação. 
De maneira similar, a forte estigmatização social sobre os devotos de religiōes de origem afro faz com que raramente eles reivindiquem sua identidade social de praticantes dessas religióes, por mais que sua prática constitua um pilar principal da elaboração de suas identidades pessoais (ser "filho" de um determinado orixá afeta fortemente a vida de uma pessoa). Também para os devotos de Gauchito Gil ou de San la Muerte, a identificação como seguidores ${ }^{18}$ desses santos constitui um elemento crucial de sua identidade pessoal e de suas crenças e práticas religiosas, por mais que sua identidade social siga sendo a de "católicos". No caso dos evangélicos, a correspondência entre identidade pessoal, social e coletiva tende a ser maior, o que ajuda a explicar sua crescente visibilidade no continente.

Sobre o "pluralismo"

A transição de um "monopólio" (das crenças legítimas) a um "mercado" náo deixa de implicar controles ou regulaçóes sobre as práticas e crenças religiosas. Ainda há um custo social inegável associado à prática de determinadas religióes. Muitas delas carecem de legitimidade social ou não são consideradas "verdadeiras religiôes" - mas crenças de qualidade inferior: "seitas", "cultos", "bruxaria", "satanismo", "superstiçóes" ou "folclore" -, sendo inevitavelmente estigmatizadas, fazendo com que seus praticantes sejam menosprezados ou temidos.

Como propóe James Beckford, embora exista um grau crescente de diversidade religiosa nas sociedades, isso não necessariamente implica pluralismo, se por pluralismo entendemos uma valoraçáo positiva dessa diversidade (2003, p. 74).

Muito pelo contrário, a valoração frequentemente desfavorável da diversidade religiosa revela a persistência de graus de regulação do "mercado religioso" - particularmente significativos, dado que, em uma época como a nossa de reivindicaçôes de minorias identitárias de todo o tipo (étnicas,

${ }^{18}$ N. T.: no original a palavra usada é "promeseros", modismo argentino que vem da palavra "promesa" e que se refere aos devotos; àqueles que pagam promessas [aos santos mencionados nesse caso]. 
de gênero, etc), a religiosa é praticamente a única "diversidade" para a qual dificilmente se reivindicam direitos. ${ }^{19}$

Por outro lado, o paradigma dominante visualiza apenas uma parte da "regulação" dos comportamentos religiosos, focalizando-se (quando o faz) principalmente na regulação religiosa estatal. Seguindo as ideias de Grim e Finke (2006), é necessário ressaltar que a regulação religiosa pode ser de dois tipos: 1) estatal, por meio de leis que pautam suas atividades, ou favorecendo alguma(s) em detrimento de outras (favoritismo estatal); mas também pode ser 2) social, mediante críticas e estigmatizaçóes que provenham de distintos atores sociais. Estes não somente podem ser religiosos (da(s) Igreja(s) tradicional(is)), como usualmente se parece acreditar, mas também e de maneira ainda mais relevante, por meio de agentes seculares (médicos, psicólogos, jornalistas, etc.) (Frigerio, 1993; Fidanza; Galera, 2014). Sempre insuficientemente considerados nos estudos sobre religião, os meios também cumprem uma importante função nessa regulação social.

Resumindo, entáo: da mesma maneira em que o paradigma dominante superestima a hegemonia do "monopólio católico" no passado e presta pouca atençáo aos esforços regulatórios do Estado e de diversos setores sociais para sustentá-lo (de maneira sempre mais ou menos precária), também subestima a contínua existência dessa regulação, em uma época de suposto "mercado religioso" (livre), na qual determinadas práticas ainda são invisibilizadas (ver Frigerio; Wynarczcyk, 2008, para o caso dos evangélicos), estigmatizadas ou, até mesmo, criminalizadas - como acontece cada vez mais na Argentina para o caso das religiōes de origem afro e para a devoção a San la Muerte (Fidanza, 2014).

Um problema mais geral, que obviamente compete aos estudos latino-americanos, mas que afeta quase toda a produção acadêmica sobre o tema, é a visão excessivamente institucionalizada que se tem da "religiáo". Boa parte dos estudos é realizada em grupos (mais ou menos) socialmente ou

${ }^{19}$ O destaque aos graus de regulação das atividades religiosas é uma das principais contribuições do "paradigma das economias religiosas" desenvolvido por Stark, Finke, Iannaccone e outros sociólogos norte-americanos (ver Frigerio, 2008, para um resumo do mesmo).

Debates do NER, Porto Alegre, ano I9, N. 34, P. 75-I2 I, Ago./Dez. 20 i 8 
academicamente legitimados como "religiosos", já que nossa tipologia deles é excessivamente restringida e influenciada pelo nosso entorno cultural cristão. A utilização cada vez mais frequente do conceito espiritualidade tenta chamar a atenção para a busca de uma experiência religiosa não institucionalizada, enfatizando a crescente relevância das bricolagens e sincretismos pessoais. Contudo, o problema é que o conceito parece dispensar a necessidade de todo grupo religioso, como se seu protagonista fosse um sujeito hiper- ou super-individualizado, que pudesse prescindir das atividades de agrupaçóes com algum grau de organização (Carozzi, 1999; Frigerio, 2016). Prevalecem, assim, tanto visóes super-socializadas quanto infrassocializadas da religiáo (ou, em sua visão individualizada, da espiritualidade), como tentarei demonstrar a seguir. Proporei, também, que a ideia de "religião vivida" - e uma definição bastante específica da mesma - pode nos ajudar a sair da excessiva dicotomizaçáo grupo-indivíduo dentro da qual parecem se situar a maioria das análises, porque não implica (de maneira explícita nem tácita) nenhum tipo de organização específica nem tampouco um individualismo extremo.

\section{SOBRE A (DEFINIÇÃO DE) "RELIGIÃO”}

\section{A RELIGIÃo COMO SISTEMA E COMO INSTITUIÇÃo}

As definições usuais de religião utilizadas nas ciências sociais superenfatizam, seja explicitamente ou implicitamente, seu grau necessário de sistematicidade e de institucionalidade.

Alguns exemplos:

"A religião é um sistema de crenças e práticas por meio das quais um grupo se enfrenta com os problemas últimos da vida humana" (Yinger, 1970, p. 7);

"Uma instituição que consiste na interação culturalmente pautada com seres supra-humanos culturalmente postulados" (Spiro, 1966);

"Um sistema de simbolos que atua para estabelecer vigorosos, penetrantes e duradouros estados anímicos e motivações nos homens, formulando 
concepçóes de uma ordem geral de existência e revestindo essas concepçóes com uma auréola de afetividade de modo que os estados anímicos e motivaçôes pareçam ser de um realismo único” (Geertz, 1973);

"Um sistema unificado de crenças e práticas relativo a uma realidade supraempírica, transcendente, que une todos aqueles que se aderem a ele com vistas a formar uma só comunidade moral” (Dobbelaere, 1981).

A ênfase em que é um sistema de crenças implica ou traz associados outros sistemas similares a respeito de sua coerência e eloquência. Os aspectos ou dimensôes discursivos (e cognitivos) das religiōes tornam-se particularmente relevantes: produz-se uma superdependência em relaçáo ao que os informantes ou os nativos podem explicar sobre o que fazem, principalmente com certo nível de complexidade e coerência. Por outro lado, a frequente insistência em que a religião se refere aos "problemas últimos da vida" também estabelece requisitos de certo desenvolvimento e consistência teológica, mais presentes nas preocupaçóes de especialistas religiosos do que em boa parte dos fiéis, que talvez, mais que desvelar as chaves últimas da existência (para quê?), utilizam a religiáo e os poderes ou seres supra-humanos como meios para aliviar os problemas de sua vida cotidiana (como?). Com essas definiçốes de religião não parece estranha a necessária relevância e dependência, nas pesquisas, de determinados "informantes-chave" - geralmente os líderes de grupos religiosos ou, no caso de sociedades simples, os xamãs ou especialistas, que são os que podem articular as crenças com esse nível requerido de desenvolvimento, complexidade e sistematicidade.

Mesmo sendo necessário reconhecer que as dimensóes da prática, da emoção e da corporalidade se tornaram mais importantes nos últimos anos (resultado da influência de Bourdieu e das perspectivas contemporâneas da performance e do embodiment), os estudos desses aspectos continuam sendo realizados em contextos claramente "religiosos" - que sempre são definidos como tais por determinados grupos sociais ou pelos preconceitos dos acadêmicos daquilo que seria "religioso".

As instituiçóes religiosas seguem tendo um papel altamente preponderante em nossos estudos. São principalmente os grupos considerados (social 
e academicamente) como legitimamente religiosos, e seus representantes ou líderes, os que facilitam os contextos principais de observação. É difícil esperar o contrário, dada nossa formação ocidental e cristã (e sociológica) que nos predispóe a buscar, encontrar e examinar, sobretudo ou principalmente, igrejas, seitas ou denominaçóes - grupos obviamente estruturados e facilmente reconhecíveis que perduram no tempo. Dessa maneira, nosso estudo da "religiáo" encontra-se excessivamente focalizado nos grupos, contextos e sistemas de crenças legitimamente (social e academicamente) consagrados como "religiosos" e deixa de fora da análise boa parte da produção "religiosa" que frequentemente náo costuma passar por esses grupos ou contextos nem conta com o grau de sistematicidade (teoricamente) requerido, mas que, não obstante, cumpre um papel muito importante na vida das pessoas - especialmente na produção de diversidade religiosa (Besecke, 2005).

Ultimamente, o conceito de espiritualidade chama a atenção para a busca de experiência religiosa não institucionalizada, enfatizando a análise das bricolagens e sincretismos pessoais. Contudo, como argumentarei a seguir, o conceito tampouco é adequado para examinar a atividade religiosa fora dos grupos legitimados, já que parece prescindir da necessidade de toda agrupação religiosa.

\section{A RELIGIÃO INSTITUCIONALIZADA VS. A RELIGIÃO INDIVIDUAL}

É possível rastrear uma armadilha conceitual que torna dependente o fazer religioso táo somente (ou, ao menos principalmente) de determinados grupos com características muito específicas ou, ao contrário, da quase absoluta autonomia do indivíduo que escolhe entre diferentes ofertas ou faz sua própria combinação delas. Pode-se identificar a origem dessa armadilha, chegando à obra de Troeltsch e sua influente tipologia de grupos religiosos.

Em 1975, a revista norte-americana Sociological Analysis (agora Sociology of Religion) convocou um simpósio sobre a obra de Troeltsch e sua relação com a de Weber. Nesse simpósio, os três artigos dedicados ao teólogo alemão insistiram em seu conceito de "misticismo", que seria o "esquecido" terceiro integrante de sua tipologia igreja-seita-misticismo. Uma complicada relaçáo 
com Weber e, em seguida, a seletiva introdução de sua obra no mundo anglófono por Niebuhr (1929) fizeram com que a sociologia da religião posterior se baseasse praticamente na dicotomia seita-igreja, deixando de lado o misticismo, o "desventurado terceiro tipo de Troeltsch" (Garrett, 1975).

Colin Campbell (1978, p. 146) resgata mais explicitamente as contribuições iniciais de Troeltsch para a análise e a adequada compreensão da "nova religiosidade" que, a partir dos anos de 1960, havia posto em xeque a teoria da secularizaçáo ("a expansão da religião oriental, o renascimento do ocultismo, o fascínio pela astrologia e o novo Pentecostalismo”). Uma religiosidade que - no momento em que escreveu o artigo - era difícil de localizar tanto dentro de noçóes estabelecidas de "o religioso" quanto de "o secular”. As dificuldades de muitos de seus colegas de enquadrá-la dentro de "o religioso" - argumenta Campbell - decorriam do fato de que as novas práticas não estavam desenvolvidas por, nem aconteciam dentro de, igrejas, seitas ou denominaçóes, as formas de agrupaçóes religiosas típicas estudadas pela sociologia da religião - e que, portanto, determinavam, academicamente, o paradigma de "o religioso".

Para Campbell (1978), entretanto, essa nova religiosidade poderia encaixar-se dentro do terceiro tipo de religiáo de Troeltsch: o da "religião mística e espiritual", um tipo bem menos conhecido e utilizado do que seus outros dois de "religião de igreja" (church religion) e "religiaao de seita" (sect religion). Como Garrett (1975), Campbell sugere que essa tricotomia religiosa original de Troeltsch havia sido reduzida a uma dicotomia com um foco excessivo no tipo de grupo religioso que as caracterizaria (igreja ou seita), fazendo com que apenas esses dois tipos de instituiçóes dominassem o panorama do estudo da religiáo. ${ }^{20}$

${ }^{20}$ Desenvolvi com maior profundidade esses assuntos ao discutir a relevância do conceito de "espiritualidade" (ver Frigerio, 2016). 
Anteriormente, Luckmann, no seu livro Invisible Religion ${ }^{21}$ (1967), havia chamado a atenção para o fato de que a religião se tornara invisível aos olhos dos sociólogos porque prestam atenção principalmente aos mundos sociais institucionalizados e organizados e dificilmente conseguem perceber o que acontece fora deles. Para Luckmann (1967, p. 22-26), a principal premissa da sociologia da religião:

Consiste na identificação da igreja e da religião [...]. A religião vem a ser um fato social, seja como ritual (comportamento religioso institucionalizado) ou doutrina (ideias religiosas institucionalizadas) [...]. A disciplina, desse modo, aceita as auto-interpretaçóes - e a ideologia - das instituiçóes religiosas como definiçóes válidas do alcance de seus temas de estudo ou de interesse.

Ainda que nos últimos vinte anos a ideia de espiritualidade venha ganhando terreno como ferramenta conceitual, focalizando em dimensóes diferentes da "religião", a situação atual dos estudos continua dependendo excessivamente das antigas formulaçóes de Troeltsch: seguimos estudando "religiáo" (sobretudo através do estudo de igrejas ou seitas) e agora também "espiritualidade" (redescobrindo e reivindicando o terceiro tipo de Troeltsch). A dicotomia "religiáo" e/ou "espiritualidade", no entanto, continua oferecendo versóes estereotipadas sobre as maneiras com que as pessoas se relacionam com o mundo sobrenatural, seja proporcionando visóes hiper-socializadas (o indivíduo subsumido dentro de sua comunidade religiosa, usualmente do tipo igreja ou seita) ou infra-socializadas (o indivíduo soberano do misticismo).

Como correçáo analítica à super-dependência nos conceitos de igreja ou seita, ideias como "religião invisível" ou "espiritualidade" ajudam a pensar outras possibilidades de prática e validação do "religioso", mas a ênfase excessivamente individualista de Luckmann, e de quem toma a versão emic da epistemologia autônoma da espiritualidade ao pé da letra, começou a ser objeto de críticas por parte de vários autores que fizeram estudos empíricos

${ }^{21}$ N.T.: Traduzido no Brasil com o título de "A religião invisível”, publicado pela Ediçôes Loyola, 2010. 
importantes sobre o tema (Wood, 2010; Frigerio, 2016). A visão do individualismo radical - que caracterizaria a espiritualidade moderna, tanto em seu momento "Nova Era" nos anos 1980 e 1990, quanto na espiritualidade pós-cristã do século XXI - foi criticada como sociologicamente inadequada. Como argumentou e mostrou Carozzi (1999), a autonomia éparte do "vocabulário de motivos" (vocabulary of motives) que se aprende dentro do circuito alternativo, em interação com diferentes grupos e seus gurus ou líderes e os outros praticantes dessas ideias. ${ }^{22}$

A visão de um indivíduo onipotente que escolhe livremente e realiza suas próprias bricolagens de acordo, principal ou exclusivamente, com sua vontade autônoma, provém da aceitação acrítica dos relatos dos entrevistados - ou de suas trajetórias narradas em livros ou apresentadas em conferências e oficinas - lidos à luz de perspectivas teóricas excessivamente individualistas. Essa conjunção teóricometodológica invisibiliza os numerosos grupos pelos quais passaram seus entrevistados, e as diversas fontes e discursos de autoridade que acataram em distintos momentos - como sugere Carozzi (1999, 2000) com base na sua experiência de campo, que complementa e guia as interpretaçóes de suas entrevistas.

Mais recentemente, outros autores anglófonos também têm enfatizado que os indivíduos sáo socializados na doutrina da "espiritualidade do self" (Aupers; Houtman, 2006, p. 208):

Satisfazendo sua fome no mercado da Nova Era, nossos entrevistados adquiriram quadros de interpretação alternativas, novos vocabulários e símbolos para interpretar suas experiências. Aprenderam a etiquetar experiências estranhas e fora do cotidiano como espirituais. Simultaneamente, essas experiências validaram os esquemas interpretativos aprendidos.

${ }^{22}$ Resenhando a clássica formulação de C. Wright Mills (1940), Campbell aponta que "a premissa é que os motivos não são mais que palavras utilizadas por atores em situaçóes nas quais precisam justificar (prestar contas de) sua conduta quando interrogados por outros" (1991, p. 90). Existem "vocabulários de motivos" típicos e específicos que se articulam em determinadas circunstâncias ou contextos sociais.

Debates do NER, Porto Alegre, Ano I9, N. 34, P. 75-I 2 I, Ago./DeZ. 20 I 8 
Besecke (2005) e Wood (2010), entre outros, criticaram a ideia de que as pessoas desenvolvem sua espiritualidade com base em critérios exclusivamente pessoais como sociologicamente naive:

No caso da sociologia da espiritualidade, um indutivismo naive fez com que as declarações dos indivíduos de que estão exercendo autoridade sobre sua vida espiritual fossem transpostas a-criticamente às afirmaçóes sociológicas de que esse é realmente o caso. Os sociólogos transformaram os discursos nativos sobre o controle da própria vida em pronunciamentos analíticos de que efetivamente se exerce a auto-autoridade [self-authority] (Wood, 2010, p. 270).

A ênfase excessiva na religiáo privada ou privatizada [privatized religion] deriva uma ideia da religião como um fenômeno exclusivamente psicológico, com poucas influências e consequências sociais (Besecke, 2005, p. 187).

Ao mesmo tempo em que o conceito de espiritualidade ganhou terreno nas últimas duas décadas, isto também ocorreu com o de "religião vivida" - um conceito que, sustento, pode ajudar a pensar mais apropriadamente a religião, para além do continuum igreja-seita e do individualismo exagerado da espiritualidade. ${ }^{23}$

\section{A “RELIGIÃo VIVIDA"}

Em contraposição a uma ênfase excessivamente institucional, focalizada na atividade de grupos religiosos organizados com certa permanência no tempo, e que se correspondem principalmente aos tipos de igreja ou seita, a ideia de religiāo vivida vem ganhando terreno aceleradamente nos últimos anos. Definida de diferentes maneiras por distintos autores, a ênfase sempre parece ser em

${ }^{23}$ Ammerman, na introdução de um livro que é um expoente clássico da perspectiva, afirma: "[...] devemos levar a sério tanto a habilidade das instituiçóes para produzir e impor padróes de significado e açáo e a habilidade dos indivíduos e grupos para improvisar e manter alternativas. Supomos que tanto a estrutura como a agência são elementos essenciais em qualquer explicação sobre a maneira em que a religião se faz presente" (2007, p. 13). 
uma perspectiva "de baixo", enraizada nas práticas cotidianas de indivíduos comuns - e não exclusiva ou principalmente na compreensão elaborada de líderes e especialistas religiosos legitimados (Ammerman, 2007, p. 5).

Tweed (2015) denomina essas novas ênfases como um "quotidian turn" (virada em direção ao cotidiano) que caracteriza, de maneira geral, como um deslocamento da atenção analítica "da religião prescrita à religião prática, dos ritos religiosos organizados e as crenças teológicas sistematizadas das elites em instituições religiosas dominantes às práticas, artefatos e contextos de devotos comuns na vida diária, incluindo momentos e lugares que podem ser considerados seculares" (p. 369-370). Acrescenta, contudo, outros elementos comuns a esses estudos que se relacionam náo somente com quem a pratica, mas com como a praticam, o que acarreta implicaçóes temporais e espaciais. Entre as primeiras, dias, momentos e épocas que não sáo as "tradicionalmente" religiosas (os domingos ou os sábados, de acordo com a tradição religiosa, ou o natal, a páscoa ou qualquer época do ano rica em rituais), mas em qualquer momento da vida das pessoas. Entre as segundas, espaços que não são, tampouco, os tradicionalmente religiosos, lugares fora daqueles institucionalmente sancionados onde os especialistas rituais oferecem ritos regulares e prescritos. Náo os templos propriamente ditos, mas a casa, a rua, as praças, os estádios, os teatros e cinemas, os hospitais, os aeroportos e a internet.

Robert Orsi é um dos autores principais e mais influentes dessa corrente. É um autor que, como aponta Tweed (2015), proporcionou, em vários de seus trabalhos, diferentes definições da religião vivida - ainda com ênfases diferentes em, por exemplo, duas ediçóes do mesmo livro. Por motivos que detalharei mais abaixo, considero particularmente útil a que oferece na introdução de seu livro Between Heaven and Earth, em que afirma:

A religiáo é comumente pensada como um meio para explicar, compreender e modelar a realidade, mas sustento que a religiäo é uma rede de relaçôes [network of relationships] entre o céu e a terra, que envolve os humanos com uma série de diferentes figuras sagradas (Orsi, 2005, p. 2, grifo nosso). 
E volta a destacar, mais adiante (em quase óbvia referência a Geertz):

Não é uma rede de significados, mas de relaçôes. [...] O que importa não são tanto as crenças..., mas as práticas, os objetos, as presenças... [...] Os deuses, santos, demônios, ancestrais e o que seja são reais na experiência e na prática, nas relações entre o céu e a terra, nas circunstâncias da vida e nas histórias [histories] das pessoas, nas estórias [stories] que as pessoas contam sobre eles. (Orsi, 2005, p. 5-18).

Essa definição tem, para os propósitos do argumento desenvolvido neste trabalho, as seguintes vantagens: a) não pressupóe praticamente nenhum grau de sistematicidade das crenças; b) tampouco considera as crenças como o elemento mais importante da vida religiosa, ressaltando a relevância de "práticas", "objetos", "presenças" - aspectos que qualquer trabalho de campo mostra que são essenciais na experiência religiosa das pessoas; c) tampouco focaliza nas funçóes cognitivas da religião (não a considera principalmente "um meio para explicar, compreender e modelar a realidade"), já que para Orsi "a religião é uma rede de relaçôes [network of relationships] entre o céu e a terra, que envolve os humanos com uma série de diferentes figuras sagradas" (2005, p. 2).

A definição é bastante minimalista, mas enfatiza duas características essenciais da vida religiosa. A primeira é o foco nas relaçôes entre humanos e figuras sagradas. Esse aspecto relacional não recebeu tanta atenção por parte dos estudiosos, dada a ênfase já mencionada em sistemas teológicos oniabrangentes e de certa complexidade. A ideia de relação não os nega, mas também não os coloca no centro da atividade religiosa legítima - as pautas que guiam essas relaçóes - e suas justificativas - podem ser muito simples, ou muito complexas.

Ademais, essas relaçóes se estabelecem com figuras sagradas. Aqui sim caberia uma perspectiva mais crítica do enunciado de Orsi, já que certas formulaçôes podem denotar uma perspectiva excessivamente cristã-cêntrica: quando fala de relaçôes "entre o céu e a terra", ou ainda, a ideia de "figuras sagradas". Se o termo "sagrado" for entendido em um sentido durkheimiano, pode pressupor um abismo demasiadamente grande entre os humanos e 
essas figuras sagradas, tergiversando ou mal interpretando a experiência de muitos fiéis para os quais o sagrado pode ser apenas parte de "uma textura diferenciada do mundo-habitado" (para utilizar a expressão de Martín, 2007, p. 77). Pessoalmente, prefiro falar de "seres supra-humanos" (ou talvez também de "poderes", para determinados contextos, principalmente, mas não apenas, indígenas), o que denotaria apenas uma capacidade de agência maior que a dos humanos ordinários, sem entrar em discussóes sobre seu grau de "sacralidade", sobrenaturalidade ou extraordinariedade. ${ }^{24}$

Desse modo, se entendemos a religião como "uma rede de relaçôes que envolve os seres humanos com uma série de diferentes seres e poderes supra-humanos", temos uma definição substantiva, bastante minimalista, mas que serve para caracterizar como "religiosos" uma série de comportamentos que não precisam estar legitimados socialmente como tal, nem acontecer dentro de determinados grupos socialmente legitimados como "religiosos", nem nos contextos que esses estipulam como corretos para atividades "religiosas", nem ser propostos por determinado tipo de agente "religioso" (socialmente legitimado). Podemos, então, buscar a religião ou os comportamentos religiosos em uma série de lugares, momentos e contextos que não são os usualmente analisados nos estudos sobre religião, e visualizar, assim, finalmente, boa parte da diversidade religiosa ocultada por nossos preconceitos teóricos.

${ }^{24}$ A ideia de supra-humano também pode ser aplicada para concepçóes imanentes do sagrado, próprias do New Age ou da "espiritualidade contemporânea". Aupers e Houtman (2007, p. 307) descrevem desta maneira as visóes sobre a natureza (verdadeiramente) sagrada de nosso self: "O principal postulado da espiritualidade pós-cristá: a crença de que, nos níveis mais profundos do self, está a centelha divina, esperando para ser despertada e suceder o self socializado. Colocar-se em contato com esse self 'verdadeiro', 'profundo' ou 'divino' não é algo rápido, mas supóe um processo prolongado de 'desenvolvimento pessoal' [...]. Restabelecer o contato com o self divino possibilita a reconexáo com uma dimensão sagrada que holisticamente conecta tudo e, dessa maneira, possibilita a superação do próprio estado de alienação. A evolução espiritual verdadeira transcende os limites desta vida porque os New Agers geralmente acreditam na reencarnação".

Debates do NER, Porto Alegre, ANo I9, N. 34, P. 75-I 2 I , Ago./DeZ. 20 I 8 
Este último ponto é importante: não pretendo que essa definição de religiäo seja a melhor, a mais correta ou universalmente válida - nem me interessa. Acredito, sim, que é útil para visibilizar a diversidade religiosa, particularmente em sociedades complexas e em nosso contexto regional latino-americano. Essa definição nos permite ver a religião fora das "religiōes", fora das instituiçôes e dos grupos usualmente considerados como tal (pela academia e pela legitimação social). Transforma em inequivocamente religiosos (para os propósitos analíticos) comportamentos que usualmente sáo deslocados, em nossos estudos e sem maior precisão conceitual, para outros campos de interesse como o "esoterismo", o "ocultismo", o "curandeirismo", a "vidência" ou a "religiosidade popular". 25

Se tudo o que temos que fazer é buscar comportamentos que postulem determinados seres supra-humanos e que sugiram maneiras de se relacionar com eles, saímos também de outra armadilha conceitual de longa data: a diferenciação taxativa entre "religiāo" e "magia", de acordo com o caráter eminentemente social ou grupal da primeira e mais individual da segunda. ${ }^{26}$ No contexto latino-americano, em que boa parte das práticas são sempre mágico-religiosas, as tentativas categóricas de diferenciá-las cumprem mais o propósito de deslegitimar (acadêmica e socialmente) algumas práticas do que

${ }^{25}$ Ressalto: transforma-os em inequivocamente "religiosos" para os propósitos analiticos - não me interessa se os nativos os consideram ou não "religiosos" - se essa categorizaçáo tiver sentido para os praticantes ou para outros membros da sociedade. É uma ferramenta heurística, não pretende refletir a realidade emic - e lembremos que os nativos tampouco concordam sobre se determinadas práticas são "religiosas", ou uma "forma de vida", ou uma "filosofia" ou, inclusive, uma "ciência".

${ }^{26}$ Uma maldição que vem desde Durkheim, quando afirma que "uma religião é um sistema unificado de práticas e crenças relativas a coisas sagradas, isto é, coisas que estáo separadas [set apart] e proibidas; crenças e práticas que unem em uma comunidade moral única chamada igreja, todos aqueles que a elas aderem" (1995 [1912], p. 44) e dedica várias páginas de seu livro clássico para diferenciá-las (1995 [1912], p. 41-44). Ver também a resenha de Belier (1995). 
compreendê-las adequadamente em seu contexto e de acordo com os critérios dos praticantes ou com critérios acadêmicos mais inequívocos (Frigerio, 1999).

Uma das principais virtudes dessa definição é que, devido a seu caráter minimalista, nos livra de uma carga que outras definiçóes (por enfatizarem sistematicidade ou institucionalidade) implicam, talvez mais implícita que explicitamente: a necessidade de algum tipo de grupo e especialista religioso que possa formular essas crenças com determinado grau de complexidade e que deem resposta aos problemas de sentido último da vida. Com essa definição não é necessária uma comunidade moral, não é necessário um dossel sagrado (como vimos, particularmente difícil de sustentar em sociedades complexas) e também não é necessário que seja um sistema que ofereça significados últimos: apenas que regule, sem importar o grau de complexidade, as relaçóes entre os humanos e os seres supra-humanos que postula como relevantes.

\section{A RELIGIÃo EM GRUPOS LÁBEIS}

Uma visão menos institucionalizada da "religião" permite ver a (crescente, mas não necessariamente inovadora) criação e difusão de crenças "religiosas" distanciadas das "instituiçôes religiosas" em cenários e contextos sociais diversos, não contemplados sob os conceitos de igreja, seita nem o de misticismo individual, liderados por agentes laicos ou "seculares" (ou não socialmente legitimados como "religiosos").

É necessário começar a considerar a relevância de múltiplos grupos lábeis, de existência efêmera e irregular (ou nem tanto), mas que, de qualquer forma, criam e transmitem crenças, práticas e experiências religiosas social e individualmente relevantes, por mais que sua capacidade para, e vontade de, incentivar identificaçôes religiosas (em níveis pessoais, sociais e coletivos) seja muito variável. Entre eles podemos considerar: grupos caseiros de oração ou de culto de todo tipo, cursos e oficinas de distinta duração, conferências, campanhas massivas no espaço público, comunidades de leitores, festas de devotos, grupos de Facebook, etc. 
A relevância de uma multiplicidade de grupos de características muito diversas foi mais geralmente reconhecida-embora nem sempre-, para o caso da Nova Era, como uma variedade de suportes sociais que tornam possível o circuito alternativo no qual transitam aqueles que vão se socializando nos quadros interpretativos oferecidos por esse movimento (Magnani, 1999; Carozzi, 1998, 2000) e aqueles que vão também, como já argumentei mais acima, aprendendo um "vocabulário de motivos" que ressalta sua própria autonomia religiosa. ${ }^{27} \mathrm{~A}$ maior predisposição em aceitar essas variadas formas de criação e disseminação de crenças e práticas, provavelmente, neste caso, se deva a que a Nova Era costuma ser considerada um fato (apenas) marginalmente religioso - lembremos de sua críptica categorização como "nebulosa místico-esotérica” ou de seu enquadramento usual dentro da espiritualidade pós-moderna. De todo modo e com poucas exceçóes, as diferentes formas de agrupamento por meio das quais se desenvolve foram observadas, mas pouco teorizadas e praticamente nunca ou pouco consideradas como parte de uma tipologia de grupos religiosos, preferindo explicaçóes mais macrossociológicas para dar conta do atrativo e da expansão desse movimento.

No entanto, a multiplicidade de grupos e contextos entre os quais se cria e transmite "religião" também é identificada dentro de outras tradiçôes religiosas. Em algumas ocasióes, isso ocorre como parte do funcionamento mais periférico ou de extensão de grupos mais tradicionalmente religiosos com diferentes graus de autonomia. Pensemos nas atividades que ocorrem fora dos templos evangélicos, em contextos "seculares" mais íntimos ou mais públicos: os grupos de oração ou de estudo bíblico, as células familiares, as campanhas evangelizadoras ou de cura - uma variedade que muito ajuda a entender o crescimento desse movimento religioso. Em outras ocasióes, constituem-se como grupos religiosos embrionários que podem ou não

${ }^{27}$ Entre as várias possibilidades de criação e disseminação das "práticas religiosas conhecidas como neoesotéricas" (Magnani, 1999, p. 113, grifo nosso), Magnani destaca: "consultórios, academias, centros, lojas, livrarias, postos, escolas, associaçóes” (p. 127). 
fazer surgir, posteriormente, grupos mais estruturados, ou ficar em estado rudimentar ou desaparecer.

Os estudos sobre espiritismo na Argentina mencionam a quantidade de grupos familiares de prática que evoluíram para "escolas", e outros que não (Gimeno; Corbetta; Savall, 2013, p. 135). A experiência etnográfica atual mostra, igualmente, a multiplicidade de situações que constituem o continuum entre "casas familiares-altares domésticos-templos constituídos" que caracteriza a prática da umbanda no país.

Em ambos os casos, tanto os espiritistas tradicionais como os umbandistas mais antigos e estabelecidos criticam fortemente a prática fora de âmbitos "apropriados" e mais institucionalizados - por mais que vários dos críticos também passaram por etapas em que participavam de, ou inclusive organizavam, cerimônias caseiras. Apesar das críticas dos agora "ortodoxos", essas situaçóes caseiras e quase-públicas (nas quais comparecem a família extensa, os amigos e também amigos dos amigos) cumprem um papel crucial na expansão dessas religióes pelo país e seguramente são, quantitativamente falando, mais importantes que os templos publicamente reconhecidos. Pablo Semán já destacou a importância das igrejas pequenas, talvez apenas extensóes das casas de pastores do bairro, para a expansão do pentecostalismo, contrapondo visóes que enfatizam, principalmente, o papel das mega-igrejas. Como afirma o autor, "as pequenas denominaçôes pentecostais conformam, além de um formato e um vetor específico do crescimento pentecostal, uma expressão particular dos conteúdos que essa expansão assume” (Semán, 2010, p. 17).

Para o caso das "devoçóes populares", a crescente existência de santuários públicos - geralmente liderados por pessoas que se transformam em mediadores privilegiados com os santos - propicia lugares onde os devotos se relacionam publicamente com os santos, interagem entre eles e declaram e reafirmam sua fé, realizando, assim, identificaçôes públicas e fortes. Além disso, obtêm cura, proteção espiritual, dançam e passam um dia entre pares e familiares. Os altares domésticos e as imagens que peregrinam por diferentes lares também proporcionam espaços de experiências religiosas 
intensas ou de criação de significados intersubjetivos heterodoxos. ${ }^{28}$ Mesmo atividades mais "individuais", como consultas a "adivinhas", "videntes" ou "curandeiras", também são significativas no estabelecimento de relações com figuras supra-humanas e na sua modificação ou intensificação. Como dentro das cosmovisóes holistas e encantadas a saúde sempre tem dimensôes espirituais-psíquicas-físicas estreitamente entrelaçadas, a intervenção (positiva ou negativa) de seres ou poderes supra-humanos costuma ser determinante como motivo de doença ou como possibilidade de cura (Semán, 2001). ${ }^{29}$

Uma releitura de nossa história religiosa realizada a partir de um paradigma como o que proponho, ou ao menos sem os antolhos teóricos habituais, encontraria numerosos exemplos similares no passado - talvez com menos variedade e certamente com mais regulação social que na atualidade, mas muito mais do que (pré) supóe um paradigma baseado principalmente na busca de grupos do tipo igreja ou seita.

\section{A RELigiấo PElos MEIOS DE COMUNiCAÇÃo, A INDÚSTRIA CULTURAL E AS REDES SOCIAIS}

Se na busca das maneiras pelas quais se transmitem os postulados sobre as formas possíveis e efetivas de nos relacionarmos com seres supra-humanos prescindíssemos da necessidade de fazer referência obrigatória e exclusivamente a grupos religiosos com características muito específicas, a contextos "apropriados" ou a atores sociais "legitimados", poderíamos constatar que uma maneira significativa, na qual esses postulados e relaçóes são criados e circulam em nossas sociedades, inclui também a indústria cultural, os meios de comunicação, as redes sociais e a internet.

${ }^{28}$ Ver Suárez $(2008,2015)$ para um detalhado estudo de caso de uma Virgem itinerante e para uma recente e rica descrição etnográfica dos diferentes contextos de culto em um bairro mexicano, ou De la Torre (2012a), para as distintas possibilidades na cidade mexicana de Guadalajara.

${ }^{29}$ Carozzi (1993) analisa minuciosamente a construção de efeitos mágico-religiosos em consultas com mães de santo - que, para muitos, não se distinguem de "videntes" ou "curandeiras". 
Esses âmbitos "seculares" também produzem, difundem e legitimam socialmente - ou, pelo contrário, deslegitimam - ideias e práticas religiosas que têm profundo impacto na forma como os indivíduos visualizam, e se relacionam com, os seres supra-humanos na sua vida cotidiana - ainda que, poucas vezes, ou muito menos do que o desejável, são considerados parte do que os acadêmicos da "religião" deveriam estudar.

Os meios massivos de comunicação (e não me refiro aos explicitamente confessionais, mas aos supostamente seculares) desempenham, ademais, um papel importante na regulação social das religióes. Durante a década de 1980, a mídia observou com estranheza - não sem surpresa - a crescente visibilidade evangélica e suas congregações em espaços "não apropriados" para encontros religiosos: estádios de futebol, praças, descampados, cinemas. Criticou suas reunióes excessivamente emocionais, a vestimenta - inusual para um "ministro religioso" - de alguns pastores, fez interpretaçóes para seu crescimento e os considerou como expressáo e demonstraçáo do decaimento urbano ou como a ponta de lança de algumas mudanças socioeconômicas, como o desaparecimento dos cinemas tradicionais (Frigerio, 2017). Por alguns anos, considerou-os como o modelo emblemático do que seriam as "seitas" que estavam invadindo o país, até que outros grupos, mais minoritários e desviantes, tomaram o seu lugar (Frigerio, 1993; Wynarzcyk, 2009). Quando os evangélicos finalmente ganharam alguma legitimidade, deixou de se interessar por eles, invisibilizou sua presença - como se dez por cento da população não fosse evangélica - e apenas se preocupou novamente com eles quando produziram grandes concentraçóes públicas no centro da cidade (Carbonelli; Mosqueira, 2008). A presença sempre vigente de espiritistas argentinos foi igualmente invisibilizada por todos os meios que, há praticamente cinco décadas, nem a notam. As religióes afro-brasileiras e a devoção a San La Muerte aparecem somente nas seções policiais, confundindo-se nas denúncias de crimes e ritos "satânicos". Melhor sorte têm as manifestaçôes “espirituais", como a Nova Era, mais afins ao paladar de determinados setores médios. Ainda quando os meios dos setores progressistas e mais intelectuais locais costumam ter uma visão mais crítica (Viotti, 2015), os jornais mais 
importantes como La Nación ou Clarín resenham as últimas tendências em termos de meditação, yoga, mindfulness, etc., e, além disso, editaram e colocaram à venda coleçôes de livros de Paulo Coelho, Osho ou Chopra.

Da mesma maneira que os meios de comunicação, a indústria cultural também cria, dissemina, legitima ou deslegitima determinadas formas de se relacionar com seres supra-humanos. Também estigmatiza, como os meios, as práticas que, por determinadas razóes, não coincidem com o modelo social do "religioso". Livros e filmes estigmatizaram as "seitas" e ajudaram a criar "pânicos morais". Vários livros sobre o perigo das "seitas" de um conhecido líder de um grupo anti-seitas tiveram muita circulação, no final dos anos de 1980 e começo dos anos de 1990, e foram vitais para justificar e direcionar o "pânico moral" sobre as seitas produzido na mídia, durante 1992 e 1993, e que afetou distintos âmbitos sociais (Frigerio; Oro, 1998). Filmes estrangeiros e séries de televisáo produzidas localmente usaram contextos e personagens "seguidores de seitas" para tornar mais atrativas e emocionantes suas tramas e colocar em perigo seus protagonistas (Frigerio, 2000).

Nas últimas duas ou três décadas, numerosos livros publicados por editoras seculares de renome validaram os milagres católicos, por meio de autores como Victor Sueiro, que popularizou a expressão "padres curadores" e ajudou a visibilizar e legitimar a Renovação Carismática Católica. Enquanto apenas as editoras evangélicas corroboram os milagres evangélicos. As diferentes apariçôes marianas, com sua misteriosa violação da ordem natural e suas curas posteriores e eventos portentosos, também foram motivo de vários livros-prodígios que não parecem encontrar, para as editoras, comparação em nenhuma outra religião local.

As editoras seculares também têm o costume de difundir as ideias dos principais gurus da Nova Era e cumprem, sem dúvida, um papel muito relevante na popularização de suas propostas. Semán e Rizo (2013, p. 80) ressaltaram a inconveniência de deslindar literatura de religião, já que os livros podem "inspirar práticas, crenças e relaçôes com o sagrado em diferentes âmbitos sociais" e moldar sensibilidades religiosas. Ao mesmo tempo, e em consonância com o mencionado mais acima, advertem contra uma visão 
demasiadamente individualizada da leitura, destacando que "a unidade de análise da leitura não é o leitor enfrentando o livro, sozinho, mas sim as redes abertas e sobrepostas que organizam modos de leitura" (p. 84).

Em um artigo conjunto em que analisam a inesperada massividade atual da Nova Era, Semán e Viotti (2015, p. 89) indicam que seus postulados:

[...] projetaram-se para além de seu espaço, do grupo ou da pequena instituição [mais típicos do circuito alternativo dos anos de 1980 e 1990] para objetos e mensagens que têm circulaçấo massiva e instauram novos formatos de comunidade. Os bestsellers, os programas de televisão e os referentes que predicam todos os suportes possíveis promovem versóes limitadas, mas possíveis do que ocorria nos formatos para iniciados que estimulam práticas intensas.

\section{CONCLUSÓES: VISIBILIZAÇÃO E ELOGIO DA DIVERSIDADE}

Nas últimas décadas, as ciências sociais ajudaram a desmistificar as construçôes nacionalistas que enfatizavam a homogeneidade cultural e étnica das sociedades latino-americanas, denunciando-as - além de inexatas - como excludentes. Contudo, quando se trata da religiáo, nós, acadêmicos, parecemos ter contribuído, pelo contrário, para fomentar as visōes de sociedades "católicas" homogêneas, abrindo espaço para a diversidade religiosa apenas nas últimas duas ou três décadas, logo após a "quebra" do monopólio católico "tradicional".

Neste trabalho, argumentei que essa perspectiva baseia-se em uma série de pressupostos e ênfases analíticas muito concretos que super enfatizam a hegemonia do monopólio católico no passado, medindo-a principal ou exclusivamente por meio das identificaçôes religiosas e estendendo esse predomínio também para a dimensão das crenças, em um salto lógico questionável e tão somente permitido pelos pressupostos teóricos subjacentes. ${ }^{30}$

${ }^{30}$ Pensemos que, atualmente, somos mais críticos em relação às identificaçôes nativas de classe ou de raça. As desconstruçóes que realizamos de autoidentificaçóes como "de classe média" ou "branco" certamente ainda náo alcançaram as de "católico".

Debates do NER, Porto Alegre, ano I9, N. 34, P. 75-I2I, Ago./Dez. 20 I 8 
Invisibiliza-se, assim, a diversidade religiosa, as diversas maneiras existentes de conceber os seres supra-humanos e as relaçôes dos humanos com eles. Naturalizando o monopólio, e sua consequente "quebra" por motivos de índole macrossociológica (advento da modernidade, etc.), são invisibilizados também os intentos de regulação muito concretos que foram feitos pelo Estado ou por diversos setores sociais (jornalistas, médicos, psicólogos, sacerdotes católicos) para reprimi-las. Uma regulação que, sem dúvida, decresce, mas que se mantém até os dias de hoje, já que certas identificaçóes religiosas continuam implicando custos sociais não menores. A academia também contribuiu para esse processo de invisibilização, assimilando as identificaçōes às crenças e deslocando numerosas manifestaçóes com dimensóes inequivocamente religiosas para terrenos limítrofes e menores como o "esoterismo", o "ocultismo", o "curandeirismo" ou a "magia".

Utilizando referentes teóricos diferentes, argumentei que o monopólio religioso é sempre sobre as crenças legítimas e não sobre o total das crenças religiosas; que é necessário considerar os distintos níveis de identificação (pessoal, social e coletiva), já que estes têm relevância díspar para sua visibilização e para a ação social e que é crucial considerar a regulaçâo das religiôes não católicas, tanto a estatal como a social.

Propus também que é necessário utilizar definiçōes de "religiáo" que náo super-enfatizem sua sistematicidade e institucionalidade, e que nossa compreensão das formas de organização social da religião está inevitavelmente (mas, sobretudo, implicitamente) condicionada pela tipologia de inspiraçẫo nitidamente cristã de Troeltsch que vê a igreja, a seita e o misticismo individual como protagonistas excludentes. Desse modo, uma grande quantidade de atores, grupos, crenças e práticas que poderiam ser considerados religiosos passam despercebidos, muito abaixo do nosso "radar" analítico.

A ênfase recente na "espiritualidade" tampouco remedia de todo a situaçấo, porque por mais que permita espreitar modalidades religiosas relevantes e mais (mas certamente náo inteiramente) inovadoras, parece quase prescindir da necessidade de grupos sociais de transmissão e socialização, provendo uma imagem infra socializada dos indivíduos. 
Não pretendo ser o primeiro nem o único a advertir sobre esses perigos, mas acredito que ressalto de maneira nova - ou ao menos muito explícita - a necessidade de certas ênfases analíticas diferentes das que atualmente predominam. ${ }^{31}$ Em primeiro lugar, proponho que a diferença entre o "antes" (monopólico) e o "agora” (pluralista), em relação à existência de diversidade religiosa, está sendo superdimensionado, principalmente por dois motivos: por condicionamentos teóricos sobre o que seria a "religião" e por prestar pouca atenção ao importante papel da regulação religiosa. Nem antes éramos tão "católicos" nem agora somos tấo "pluralistas" - ainda que esteja claro que há diferenças importantes quanto a isso nos distintos países da região. Sempre houve maior diversidade do que acreditamos, mas regulada e reprimida em diferentes graus pelo Estado e determinados setores sociais. Atualmente, continua havendo regulação estatal e social - esta última, principalmente, desconsiderada pelos estudiosos. Em segundo lugar, advogo especialmente pelos benefícios de uma definição principalmente relacional da religião - que não precisa de determinadas e específicas formas de ancoragem social para defini-la como tal nem de certos graus de sistematicidade ou complexidade teológica, assim como tampouco há a necessidade de produzir identificaçóes religiosas. Em terceiro lugar, considero que esta definição seja especialmente adequada, pelas razóes anteriormente ditas, para visualizar a existência de conteúdos religiosos produzidos e difundidos fora das agrupaçôes tradicionalmente definidas como "religiosas", em grupos lábeis de múltiplas características, liderados por agentes - reconhecidos como

31 Além dos trabalhos que mencionei, ver Steil e Toniol (2013) para uma crítica do conceito de "religião"; De la Torre (2012a e 2012b) para outras maneiras de pensar a relação entre a religiáo institucional e a espiritualidade individualizada e para reflexóes mais gerais sobre o lugar da religião na atualidade; Parker (2008) sobre a criatividade do sujeito religioso; Martín (2007) sobre o incômodo a respeito das abordagens usuais sobre a "religiosidade popular" e a proposta do termo alternativo "práticas de sacralização"; Suárez (2008) para uma análise detalhada do papel de agentes para-eclesiais na devoção a uma Virgem mexicana; Ceriani (2013) para uma discussão dos conceitos de espiritualidade e religião; e Ludueña (2013) para uma discussão das diversas possibilidades que mediam entre a instituição e o indivíduo - entre várias outras referências relevantes possíveis.

Debates do NER, Porto Alegre, ANo I9, N. 34, P. 75-I 2 I , Ago./DeZ. 20 I 8 
religiosos ou não - e também pelos meios de comunicação, pela indústria cultural e pelas redes sociais. A presença desse tipo de grupos e de agentes religiosos não legitimados socialmente (ou apenas parcial e localmente, em seus bairros), em geral, foi abordada apenas quando se tratou da "religiosidade popular" - uma categoria a qual pouco me referi neste trabalho por sua extrema imprecisão e porque quero ressaltar a relevância desses grupos em muitos outros contextos que vão além dela, em outras tradiçóes religiosas e, ainda, em âmbitos considerados "seculares". Meu argumento excede em muito o âmbito usual de referência da "religiosidade popular", e eu até advogaria pelo abandono deste conceito que confunde muito mais do que contribui para a análise. Em quarto lugar, embora seja muito provável que o nível de autonomia religiosa no mundo contemporâneo seja maior do que nunca, no passado, era bem menor o grau com que as instituiçóes religiosas conseguiam controlar as relaçóes de seus fiéis com os seres supra-humanos do que aquele que estamos tomando como paradigmático. A distinção taxativa entre o "antes" de consciências monopolizadas pela Igreja e o "agora" de indivíduos "crentes a sua maneira" estereotipa em excesso ambas as situaçóes e obvia - repito - o papel da regulação religiosa que exigia, no passado, um acatamento formal e público que não chegava necessariamente a afetar as relaçôes íntimas dos indivíduos com o mundo sobre ou supranatural. Devemos questionar com maior convicção - se é que por acaso o fazemos a prevalecente construçáo acadêmica dos indivíduos eclesiasticamente super socializados do passado e os infra socializados e excessivamente autônomos do presente - ou a presunção naturalizada, que sabemos errônea, de que os tipos ideais refletem exatamente o estado das coisas.

A diversidade, proponho então, não está na quantidade de denominaçóes ou igrejas ou religióes diferentes que possa haver, nem tampouco na quantidade de pessoas que se identificam com elas, nem na quantidade de denominações que possam efetivamente criar identificações religiosas duráveis ou sustentadas. Está, na verdade, na quantidade de diferentes seres supra-humanos postulados e nas múltiplas maneiras de relacionar-se com eles, nas numerosas e complexas reinterpretaçóes de seus principais atributos, 
na quantidade quase ilimitada de grupos lábeis de todo tipo que as criam e que transmitem os símbolos que representam esses seres e as heterogêneas maneiras de compreendê-los.

Esses grupos, e os significados, práticas e símbolos que propiciam não são socialmente irrelevantes por não se traduzirem em identificaçôes que possam levar à contagem massiva de indivíduos. Não aparecer necessariamente em estudos quantitativos não quer dizer que não existam, já que não somente os números refletem adequadamente a relevância ou a ubiquidade de determinadas concepçóes e comportamentos. Longe de ser socialmente desdenháveis por não poderem ser quantificadas segundo nossas técnicas de pesquisa usuais, estas múltiplas visóes das maneiras de se relacionar com os seres supra-humanos têm complexas repercussóes sobre concepçóes nativas sobre a saúde, a justiça, as relaçóes de gênero, a política, as relaçóes com o poder e os poderosos, a conflituosidade ou solidariedade nos laços sociais, etc. Da mesma forma que são múltiplas as formas em que nos relacionamos com seres supra-humanos, também o são as maneiras em que essas relaçóes afetam as distintas dimensões de nossa existência, muito além das consideradas (apenas) como "religiosas".

\section{REFERÊNCIAS}

AMMERMAN, N. (Ed.). Everyday religion: observing modern religious lives. Oxford: Oxford University Press, 2007.

AUPERS, S.; HOUTMAN, D. Beyond the spiritual supermarket: The social and public significance of New Age Spirituality. Journal of Contemporary Religion, Londres, v. 21, n. 2, p. 201-222, 2006.

BASTIAN, J. P. La nouvelle economie religieuse de l' Amerique Latine. Social Compass, New York, v. 53, n. 1, p. 65-80, 2006.

BECKFORD, J. Social theory and religion. Cambridge: Cambridge University Press, 2003. 
BELIER, W. Religion and magic: Durkheim and the Année sociologique group. Method \& Theory in the Study of Religion, Boston, v. 7, n. 2, p. 163-184, 1995. BERGER, P. El dosel sagrado. Buenos Aires: Amorrortu, 1971.

BESECKE, K. Seeing Invisible Religion: Religion as a societal conversation about transcendent meaning. Sociological Theory, Washington, v. 23, n. 2, p. 179-196, 2005.

. Speaking of meaning in modernity: Reflexive spirituality as a cultural resource. Sociology of Religion, Oxford, v. 62, n. 3, p. 365-381, 2001.

BIANCHI, S. Historia de las religiones en la Argentina: las minorías religiosas. Buenos Aires: Sudamericana, 2004.

BUBELLO, J. Historia del esoterismo en la Argentina. Buenos Aires: Biblos, 2010. CAMPBELL, C. Reexamining Mills on motive: a character vocabulary approach. Sociological Analysis, Oxford, v. 52, n. 1, p. 89-97, 1991.

. The secret religion of the educated classes. Sociological Analysis, Oxford, v. 39, n. 2, p. 146-156, 1978.

CARBONELLI, M.; MOSQUEIRA, M. "Luis Palau en Argentina”: construcción mediática del cuerpo evangélico, disputa por el espacio público y nuevas formas de territorialidad. Enfoques, Província de Entre Ríos, v. 20, n. 2, p. 153-175, 2008.

CAROZZI, M. Nueva Era y Terapias Alternativas: Construyendo Significados en el Discurso y la Interacción. Buenos Aires: Universidad Católica Argentina, 2000.

. La autonomía como religión: la nueva era. Alteridades, Ciudad de México, v. 9, n. 18, p. 19-38, 1999.

. El concepto de marco interpretativo en el estudio de movimientos religiosos. Sociedad y Religión, Buenos Aires, n. 16-17, p. 33-59, 1998. 
. Consultando a una Mãe de Santo: un análisis de la construcción social del efecto mágico. Revista de Investigaciones Folklóricas, Buenos Aires, n. 8, p. 68-78, 1993.

. La conversión a la Umbanda en el Gran Buenos Aires. Informe final no publicado. Buenos Aires: CONICET, 1992.

CERIANI, C. Diversidad religiosa y pluralismo espiritual: notas para repensar las categorías y sus dinámicas de producción. Corpus, Mendoza, v. 3, n. 2, 2013. Disponível em: <https://journals.openedition.org/corpusarchivos/582>. Acceso em: 20 dez. 2013.

CHAVEZ, F.; MAURIZI, A.; HORVATH, R. Los manosantas. Buenos Aires: Todo es Historia, 1977.

DA COSTA, N. Religión y sociedad en el Uruguay del siglo XXI: un estudio de la religiosidad en Montevideo. Montevideo: CLAEH, 2003.

DE LA TORRE, R. Religiosidades nómadas: creencias y prácticas religiosas heterodoxas en Guadalajara. Guadalajara: La Casa Chata, 2012a.

. La religiosidad popular como "entre-medio" entre la religión institucional y la espiritualidad individualizada. Civitas, Porto Alegre, v. 12, n. 3, p. 506-521, 2012b.

. El catolicismo: ¿un templo en el que habitan muchos dioses? In: FORTUNY, P. (Ed.) Creyentes y creencias en Guadalajara. Juárez: CONACULTA; INAH, 1999. p. 101-131.

DI STEFANO, R. Reflexiones de los autores sobre el dossier. Corpus, Mendoza, v. 3, n. 2, p. 2-23, 2013. Disponível em: <http://corpusarchivos.revues. org/617>. Acesso em: 20 dez. 2013.

DOBBELAERE, K. Secularization: a multidimensional concept. Current Sociology, Madrid, v. 29, n. 2, p. 3-153, 1981.

DURKHEIM, E. The Elementary Forms of Religious Life. New York: Free Press, 1995 [1912]. 
ESQUIVEL, J. et al. Creencias y religiones en el Gran Buenos Aires: el caso de Quilmes. Buenos Aires: Universidad Nacional de Quilmes, 2001.

FIDANZA, J. Regulaciones sociales y gubernamentales de la religión: el caso de una devoción popular problematizada. 2014. Tesis (Maestría) - Curso de Ciencias Sociales, Pontificia Universidad Católica Argentina, Buenos Aires, 2014. FIDANZA, J.; GALERA, C. Regulaciones a una devoción estigmatizada: Culto a San La Muerte en Buenos Aires. Debates do NER, Porto Alegre, v. 1, n. 25, p. 171-196, 2014.

FINKE, R. The consequences of religious competition: Supply side explanations for religious change. In: YOUNG, L. (Ed.) Rational Choice theory and religion. New York: Routledge, 1997. p. 45-64.

FORTUNY, P. (Ed.) Creyentes y creencias en Guadalajara. Juárez: CONACULTA; INAH, 1999.

FRIGERIO, A. Religion out of place: social regulation of evangelical expansion in Buenos Aires. In: MAPRIL, J. (Ed.) et al. Secularisms in a Postsecular Age? Religiosities and Subjectivities in Comparative Perspective. New York: Palgrave Macmillan, 2017. p. 275-293.

. La ¿"nueva"? espiritualidad: Ontología, epistemología y sociología de un concepto controvertido. Ciencias Sociales y Religión/Ciências Sociais e Religiäo, Porto Alegre, v. 18, n. 24, p. 209-231, 2016.

. Nuestra elusiva diversidad religiosa: cuestionando categorías y presupuestos teóricos. Corpus, Porto Alegre, v. 3, n. 2, 2013a. Disponível em: <http://corpusarchivos.revues.org/313>. Acceso em: 20 dez. 2013.

Lógicas y límites de la apropiación new age: donde se detiene el sincretismo. In: DE LATORRE, R.; ZÚNIGA, C.; HUET, N. (Ed.). Variaciones y apropiaciones del new age en América Latina. Guadalajara: CIESAS, 2013b. p. 67-85. 
. O paradigma da escolha racional: mercado regulado e pluralismo religioso. Tempo Social, São Paulo, v. 20, n. 2, p. 17-39, 2008.

. Repensando el monopolio religioso del catolicismo en la Argentina. In: CAROZZI, M.; CERIANI, C. (Ed.). Ciencias sociales y religión en América Latina. Buenos Aires: Biblos, 2007. p. 87-118.

. Outside the nation, outside the diaspora: accomodating race and religion in Argentina. Sociology of Religion, Oxford, v. 63, n. 3, p. 291-315, 2002.

. "No será una secta?”: Imágenes de problemas sociales en programas televisivos de ficción. Cuadernos de Antropología Social, Buenos Aires, n. 11, p. 387-404, 2000.

. El futuro de las religiones mágicas en Latinoamérica. Ciencias Sociales y Religión/Ciências Sociais e Religião, Porto Alegre, v. 1, n. 1, p. 51-88, 1999.

. La invasión de las sectas: el debate sobre nuevos movimientos religiosos en los medios de comunicación en Argentina. Sociedad y Religión, Buenos Aires, v. 10, n. 11, p. 24-51, 1993.

FRIGERIO, A.; ORO, A. “Sectas satánicas” en el Mercosur: un estudio de la construcción de la desviación religiosa en los medios de comunicación de Argentina y Brasil. Horizontes Antropológicos, Porto Alegre, v. 4, n. 8, p. 114-150, 1998. FRIGERIO, A.; WYNARCZYK, H. La diversidad religiosa en Argentina: un desafío a la ciencia normal. Cultura \& Religión, Santiago, v. 7, n. 1, p. 3-9, 2013.

- Diversidad no es lo mismo que pluralismo: cambios en el campo religioso argentino (1985-2000) y lucha de los evangélicos por sus derechos religiosos. Sociedade e Estado, Brasília, DF, v. 23, n. 2, p. 227-260, 2008.

. Cult controversies and government control of new religious movements in Argentina. In: RICHARDSON, J. (Ed.). Regulating religion: case studies from around the globe. New York: Kluwer Academic Publishers, 2003. p. 453-475. 
GARRET, W. Maligned mysticism: the maledicted career of Troeltsch's third type. Sociological Analysis, Oxford, v. 36, n. 3, p. 205-223, 1975.

GEERTZ, C. Religion as a cultural system. In: . The interpretation of cultures. New York: Basic Books, 1973.

GIMENO, J.; CORBETTA, J.; SAVALL, F. Cuando hablan los espiritus: historias del movimiento Kardeciano en la Argentina. Buenos Aires: Antigua, 2013. GOFFMAN, E. Stigma: notes on the management of spoiled identity. New York: Simon and Schuster, 1986.

GRIM, B.; FINKE, R. International Religion Indexes: government regulation, government favoritism, and social regulation of religion. Interdisciplinary Journal of Research on Religion, Waco, v. 2, n. 1, p. 1-40, 2006.

HERVIEU-LÉGER, D. Secularization and religious modernity in Western Europe. In: SHUPE, A.; MIZTAL, B. (Ed.). Religion, mobilization and social action. Westport: Praeger, 1998. p. 15-31.

. La religion pour mémoire. Paris: Cerf, 1993.

HOUTMAN, D.; AUPERS, S. The spiritual turn and the decline of tradition: the spread of post-christian spirituality in 14 Western countries, 1981-2000. Journal for the Scientific Study of Religion, Medford, v. 46, n. 3, p. 305-320, 2007.

LUCKMANN, T. The Invisible Religion: the problem of religion in modern society. Londres: Macmillan, 1967.

LUDUEÑA, G. La diversidad religiosa entre las certezas del paradigma del monopolio. Corpus, Mendoza, v. 3, n. 2, 2013. Disponível em: <http:// corpusarchivos.revues.org/580>. Acesso em: $20 \mathrm{dez} .2013$.

MAGNANI, J. Mystica Urbe: um estudo antropológico sobre o circuito neo-esotérico na metrópole. São Paulo: Studio Nobel, 1999.

MALLIMACI, F. Prólogo. In: ESQUIVEL, J. et al. Creencias y religiones en el Gran Buenos Aires: el caso de Quilmes. Buenos Aires: Universidad Nacional de Quilmes, 2001. p. 13-31. 
MARTÍN, E. Aportes al concepto de "religiosidad popular": una revisión de la bibliografía argentina. In: CAROZZI, M.; CERIANI, C. (Ed.). Ciencias sociales y religión en América Latina. Buenos Aires: Biblos; ACSRM, 2007. p. 61-86.

MILLS, C. Situated Actions and Vocabularies of Motive. American Sociological Review, Washington, v. 5, n. 6, p. 904-913, 1940.

NIEBUHR, R. The social sources of denominationalism. New York: Holt, 1929. ORSI, R. Between Heaven and Earth: the religious worlds people make and the scholars who study them. Princeton: Princeton University Press, 2005. PARKER, C. Mentalidad religiosa post-ilustrada: creencias y esoterismo en una sociedad en mutación cultural. In: ALONSO, A. (Ed.). América Latina y el Caribe: territorios religiosos y desafíos para el diálogo. Buenos Aires: CLACSO, 2008. p. 337-364.

POLLETA, F; JASPER, J. Collective identity and social movements. Annual Review of Sociology, Palo Alto, v. 27, p. 283-305, 2001.

QUEREILHAC, S. Cuando la ciencia despertaba fantasías: prensa, literatura y ocultismo en la Argentina de entre siglos. Buenos Aires: Siglo XXI, 2016. RATIER, H. La medicina popular. Buenos Aires: CEAL, 1972.

SANTAMARIA, D. Ocultismo y espiritismo en la Argentina. Buenos Aires: CEAL, 1992.

SEMÁN, P. Pluralismo religioso en una sociedad de pluralidad jerarquizada. Corpus, Mendoza, v. 3, n. 2, 2013. Disponível em: <http://corpusarchivos. revues.org/584>. Acesso em: 20 dez. 2013.

. De a poco mucho: las pequeñas iglesias Pentecostales y el crecimiento pentecostal. Cultura \& Religión, Santiago, v. 4, n. 1, p. 16-33, 2010. . Cosmológica, Holista y Relacional: una corriente de la religiosidad popular contemporánea. Ciencias Sociales y Religión/Ciências Sociais e Religião, Porto Alegre, v. 3, n. 3, p. 45-74, 2001. 
SEMÁN, P.; RIZO, V. Tramando religión y bestsellers: La literatura masiva y la transformación de las prácticas religiosas. Alteridades, Ciudad de México, v. 23, n. 45, p. 79-92, 2013.

SEMÁN, P.; VIOTTI, N. "El paraíso está dentro de nosotros": la espiritualidad de la Nueva Era, ayer y hoy. Nueva Sociedad: democracia y política en América Latina, Buenos Aires, n. 260, p. 81-94, 2015.

SNOW, D. Collective identity and expressive forms. In: SMELSER, N. (Ed.); BALTES, P. (Org.). International Encyclopedia of the Social \& Behavioral Sciences. Palo Alto: Elsevier Science, 2001. p. 2212-2219.

SPIRO, M. Religion: problems of definition and explanation. In: BANTON, M. (Org.). Anthropological approaches to the study of religion. New York: Praeger, 1966. STARK, R.; IANNACCONE, L. Rational choice propositions about religious movements. Religion and the Social Order, Leiden, n. 3A, p. 241-261, 1993. STARK, R.; McCANN, J. Market forces and Catholic commitment: exploring the new paradigm. Journal for the Scientific Study of Religion, Medford, v. 32, n. 2, p. 111-124, 1993.

STEIL, C.; TONIOL, R. A crise do conceito de religião e sua incidência sobre a antropologia. In: GIMÉNEZ, V. (Org.); GIUMBELLI, E. (Ed.). Religión, cultura y politica en las sociedades del siglo XXI. Buenos Aires: Biblos, 2013. p. 137-155.

STONE, G. Appearance and the self. In: ROSE, A. (Ed.). Human behaviour and social processes. Boston: Houghton Mifflin, 1962, p. 86-118.

SUÁREZ, H. Creyentes Urbanos: sociología de la experiencia religiosa en una colonia popular de la ciudad de México. Ciudad de México: UNAM, 2015.

. Peregrinación barrial de la Virgen de San Juan de los Lagos en Guanajuato. Agentes para-eclesiales. Archives de Sciences Sociales des Religions, Paris, n. 142, p. 87-111, 2008. 
TWEED, T. After the quotidian turn: Interpretive categories and scholarly trajectories in the study of religion since the 1960s. The Journal of Religion, Chicago, v. 95, n. 3, p. 361-385, 2015.

VIOTTI, N. El affaire Ravi Shankar: neo-hinduismo y medios de comunicación en Argentina. Sociedad y Religión, Buenos Aires, v. 25, n. 43, p. 13-46, 2015. WEIGERT, A.; TEITGE, J.; TEITGE, D. Society and identity. Cambridge: Cambridge University Press, 1986.

WOOD, M. The sociology of spirituality: reflections on a problematic endeavor. In: TURNER, B. (Org.). The New Blackwell Companion to the Sociology of Religion. London: Wiley-Blackwell, 2010. p. 267-285.

WRIGHT, P.; MESSINEO, M. La producción cultural del imaginario esotérico. Una visita desde Buenos Aires. Cultura y Religión, Chicago, v. 7, n. 1, p. 30-41, 2013.

WYNARCZYK, H. Ciudadanos de dos mundos. El Movimiento evangélico en la vida pública argentina 1980-2001. Buenos Aires: UNSAM EDITA, 2009. YINGER, M. The scientific study of religion. New York: Macmillan, 1970.

Recebido em: 22/06/2018 Aprovado em: 01/07/2018 
